\title{
FACTORS ASSOCIATED WITH THE USE OF TRADITIONAL BIRTH ATTENDANT IN EILOGO, EAST NUSA TENGGARA
}

\author{
Atalia Pili Mangngi'), Pius Weraman'), Paula Tibuludji3) \\ Masters Program in Public Health, Universitas Nusa Cendana, Kupang
}

\begin{abstract}
Background: Despite advances in modern healthcare, traditional birth attendant (TBA) have continued to be utilized in rural communities in East Nusa Tenggara, Indonesia. Lack of access to quality health care, lack of skilled health workers, low education, and poverty are some of the structural factors contribute to high maternal and infant mortality in rural areas. The purpose of this study was to determine factors associated with the use of traditional birth attendant in Eilogo, Sabu Raijua, East Nusa Tenggara, Indonesia.

Subjects and Method: A cross sectional study was carried out in Eilogo, Sabu Raijua, East Nusa Tenggara, Indonesia, in 2018. A sample of 66 postpartum mothers was selected for this study. The dependent variable was the use of TBA. The independent variables were maternal education, knowledge, and social culture. The data were collected by questionnaire and analyzed by a multiple logistic regression.

Results: Low maternal education $(\mathrm{OR}=1.15 ; 95 \% \mathrm{CI}=0.19$ to $0.32 ; \mathrm{p}<0.001)$ increased maternal choice to use TBA. Good maternal knowledge $(\mathrm{OR}=0.31 ; 95 \% \mathrm{CI}=$ 0.31 to $0.94 ; \mathrm{p}<0.001)$ and modern society $(\mathrm{OR}=0.07 ; 95 \% \mathrm{CI}=0.31$ to $0.30 ; \mathrm{p}<0.001)$ decreased maternal choice to use TBA.

Conclusion: Low maternal education increases maternal choice to use TBA. Good maternal knowledge and modern society decrease maternal choice to use TBA.
\end{abstract}

Keywords: traditonal birth attendant, birth delivery, social culture

\section{Correspondence:}

Atalia Pili Mangngi. Masters Program in Public Health, Universitas Nusa Cendana, Kupang 85001, East Nusa Tenggara, Indonesia. Email: ataliapm90@gmail.com. Mobile: 082339139236. 